JOALL (JOURNAL, (DF APPIIEI) IINGUIS'ITCS ANI) II'TIRA'TURE)

Vol. 5 No. 1, 2020

ISSN (print): 2502-7816; ISSN (online): 2503-524X

Available online at https:/ / ejournal.unib.ac.id/index.php/joall/index

doi: $\underline{\text { http:/ / dx.doi.org/10.33369/joall.v5i1.9403 }}$

\title{
THE EFFECT OF GENRE BASED APPROACH ON STUDENTS' WRITING ABILITY OF RECOUNT TEXT
}

\author{
Dina Maryana Mastura', Safnil Arsyad ${ }^{2}$, Irwan Koto ${ }^{3}$ \\ Universitas Bengkulu1,2,3
}

Corresponding email: dinamaryam9@gmail.com

\begin{abstract}
The objective of this research was to investigate the effect of genre based approach on students' writing ability of recount text. This study was conducted through quasi experimental design. The population were the total of 52 second year students of SMAN 05 Bengkulu Tengah (IPS ${ }_{1}$ as experimental class dan IPS $_{2}$ as control class). The experimental class was taught by using genre based approach and the control class was taught by using the conventional approach.The instrument was a written test of a recount text. Before analyzing the data by using $\mathrm{t}$-test, a normality and homogenity test were conducted, then scored by using assessment rubric of Heaton (1988). The result showed that there was significant effect of genre based approach on students' writing ability of recount text. The effects were on the content, organization, vocabulary, language use, and mechanics.
\end{abstract}

Keywords: Writing ability, genre based approach.

\section{INTRODUCTION}

Writing is one of the most important skills in English as a foreign language (EFL). Clay, 1983 (cited in Kim \& Kim, 2005) claims that writing as a skill is very paramount for many reasons, one of them as attempting to communicate in the new mode that students most effectively discover and master the relationship between speech and written text.

As an important skill, it should make the writing itself be an ability that must be mastered by the students. On the contrary, teaching writing for EFL learners is challenging, as what Kim and Kim (2005) argue, EFL learners mostly face time constraints in learning writing. Furthermore, regarding to the argument, Richard (2006) states that from those four language skills to be taught at schools, writing is the most difficult for the teachers and students. 
It also supported by some research in many countries which use English as a foreign language. In the student's context, when they do write, they find themselves confused with word choice, correct grammatical use, organization and the generation of ideas (Gao, 2009). The same research conducted in Vietnam, Taiwan, Thailand, Korea, Kenya, and Indonesia that concluded the EFL students have to face many problems when learning to write compositions in English, and specific writing settings had the progress slowly (Trong, 2011; Yang, 2012; Kim, 2012; Ann, Somba, Obura, Njuguna, Itevete, Mulwa, and Nooh, 2015; Alwasilah, 2001).

The difficulties of writing also experienced by the the second year of social Department of SMAN 05 Bengkulu Tengah. Based on the data of student's writing test score on December 20I7, there were 20 students of 30 students got score below 75 (the minimum standar of passing grade). It means only $38 \%$ succeeded and $62 \%$ students failed in writing test, more than a half students in the classroom got remedial. Regarding to those problem, the researcher suppose if the teachers implement all activities that they should do in every stage of genre based approach, the students should have been able to produce the texts written.

The interview that has been done to some students concluded that the low of student's score because of the difficulties of the students to express ideas in writing. It took them a long time to find out the idea to write. In addition, once they got ideas for their writing, the students were still struggling in putting these ideas in reasonable, coherence, and cohesive. Problems still occurred in terms of grammar, vocabularies and punctuation. All these problems are mentioned as the component of writing, as Heaton (1988) states that writing components are the elements used in measuring a writing test; content, organization, vocabulary, language use and mechanics.

The teaching approach is estimated convenient to the teaching writing is the approach that can make students has more time to prepare the topic that will be writtten and develop the idea of writing, so that writing as a proses will be easier. One of the approach is genre based approach. This approach focuses on the understanding and production of selected genres of texts. It have been identified by Richards (2006) as a major trend in English language teaching (ELT) in the new millennium. The implementation of genre based approach with the stages, has implemented in many countries and effective proved. The effectiveness of genre-based approaches in teaching writing has been widely acknowledged in a large number of experimental and theoretical studies (such as Burns, 2001 cited in Budairi, 2015; and Kongpetch, 2006) that investigated the effectiveness of using genre based approach in teaching writing to improve students writing skills for English major students. This research will conducted to investigate the effect of genre based approach on students' writing ability of recount text at the 
second year students of SMAN 05 Bengkulu Tengah. The research is expected to give valuable contribution on genre based approach for teaching and learning English, especially in teaching writing. Hypothesis of this research is that there is significant effect of genre based approach on students' writing ability of recount text at second year of social department students of SMAN 05 Bengkulu Tengah in academic year 2018/2019. The effect can be seen from component of writing, namely content, organization, vocabulary, language use, and mechanics quality.

\section{METHODS}

\section{Participants / Subject / Population and Sample}

This study conducted through the application of experimental study. Experimental is the appropriate of the quantitative designs which is used to decide probable cause and effect (Creswell, 2012). Quasi experimental design is kind of experimental used in this research because it had not have random assignment of subjects to groups or other strategies to control extraneous variables. Seniati (2011) said that in quasi experiment the subject of the research is not randomized, it is done based on the class readily available.

\section{Instruments}

A test was used by the researcher in collecting data taken by pre test and post test consist of scored by using the rubric for the writing ability adapted from Heaton (1988). A test of writing a recount text conducted to the all the population were taken as samples. They were second year students of social department of SMAN 05 Bengkulu Tengah which consist of 52 students of two classes (XI IPS 1 and XI IPS 2 ).

\section{Data Analysis Procedures}

The data was analyzed by using $t$-test formula with SPSS (statistical package for Social Science) version 17.0. Before conducting the test of hypothesis, it was done requirements test, they were normality and homogeneity test. Normality test would be analyzed by using Kolmogorov-Smirnov and homogeneity test was analyzed by using Levene test.

\section{FINDINGS}

Result of the research showed there is significant effect of genre based approach on students' writing ability of recount text at second year of social department students of SMAN 05 Bengkulu Tengah in academic year $2018 / 2019$. The effect can be seen from component of writing, namely content, organization, vocabulary, language use, and mechanics quality. 
All of the component of writing (content, organization, vocabulary, language use, and mechanics) showed $t$-test score with significant (2-tailed) $>0.05$ in pre-test meant that Ho accepted that there is no difference on content quality of students and score $<0.05$ in post-test meant that Ho rejected that there is difference on content quality of students. The Scores can be seen on the Table 1 below.

Table: 1 Scores of t-test components of writing ability

\begin{tabular}{|l|c|c|}
\hline \multirow{2}{*}{ Component of Writing } & \multicolumn{2}{|c|}{ Scores of t-test with significant (2-tailed) } \\
\cline { 2 - 3 } & \multicolumn{2}{|c|}{ Experimental and Control Class } \\
\cline { 2 - 3 } & Pre-test & Post-test \\
\hline Content Quality & 0.357 & 0.04 \\
\hline Organization Quality & 0.832 & 0.00 \\
\hline Vocabulary Quality & 0,357 & 0.04 \\
\hline Language Use Quality & 0,529 & 0,004 \\
\hline Mechanic Quality & 0,346 & 0.004 \\
\hline
\end{tabular}

\section{DISCUSSION}

The writing ability of recount text students by using genre based approach has effect on students writing ability. This result was similar to research findings of Elshirbini and Elashri (2013) who found that there is the effectiveness of using genre-based approach in developing students' writing performance and attitudes towards writing. The effect of genre based approach on students' writing ability was shown in content, organization, vocabulary, language use and mechanics quality of students' writing. It compatible to the results is similar to the research finding of Agesta and Cahyono (2017) who found that there was a significant effect of genre approach on the students' writing achievement, covering four writing components: organization, vocabulary, grammar, and mechanics.

This result was similar to the research finding of Wang (2013) who investigated genre-based approach in writing and the results of the study indicated that learners did writing better when they were made aware of structure and providing models seem to increase the salience of the communicative moves considered by the learners for inclusion in their texts. The results is also similar to the research finding of Belmekki \& Sekkal (2018) who found that there was an effect of process-genre approach on the language choice of ESP students' writing achievement. The limitations of this research were reviewed from several factors, such as this research was only conducted in one place, namely SMAN 05 Bengkulu Tengah, so the number of samples in this study came from a narrow population. Then, the results of 
this study were not yet strong enough to be generalized elsewhere unless they had the same characteristics as the research sample. Then, a number of meetings in learning take place at noon, so that the results of activity in the classroom and the learning outcomes given were not optimal.

\section{CONCLUSION AND SUGGESTION}

Based on the research findings, it can be concluded that there is the effect of genre based approach on students' writing ability at the second year students of SMAN 05 Bengkulu Tengah. The researcher proposed the suggestion for teacher to replace the conventional approach currently applied by teachers in learning writing ability with the use of genre based approach by paying attention to the teaching design and the use of assistive devices that support the application of these approach, for more effective. Then, because of most students had weaknesses on quality of vocabulary, so it is expected that the students to find out the way in improving their ability in writing of vocabulary component such as sophisticated range, effective word or idiom choice and usage, choosing effective word, sentence styles and word choice, precise vocabulary usage, and good order of words. For further researchers, because this learning method cannot yet be generalized to all schools, it is expected that subsequent researchers will conduct research genre based approach by using different variables, subjects, and research compositions.

\section{REFERENCES}

Agesta, S \& Cahyono, Y.B. (2017). Effect of process-genre approach on the Indonesian EFL writing achievement across personality. International Journal of English Language and Linguistics Research, 5(3), 39-48.

Alwasilah, A.C. (2001). Language, culture, and education. Bandung, Indonesia. Andira.

Belmekki, A \& Sekkal, F. (2018). The effect of process-genre approach on ESP students' achievement in writing. European Journal of Research and Reflection in Educational Science, 6 (2): 9-10. www.idpublications.org

Budairi, A. (2015). Revisiting the 2006 school level curriculum and the genre based approach in the context of EFL curriculum development in Indonesia. Ahmad Dahlan Journal of English Studies, 2(3), 31-38.

Creswell, J.W. (2012). Educational research: planning, conducting, and evaluating quantitative and qualitative research. Boston, MA: Pearson.

Elshirbini, I.I., \& Elashri, A.E. (2013). The effect of the genre based approach to teaching writing on the EFL Al-azhr secondary students' writing skills and their attitudes towards writing. Journal of Education and Practice, 4(1), 45-60, 1-20. 
Gao, J. (2009). Teaching writing in Chinese Universities: finding an eclectic approach. Asian EFL Journal, 7(5), 102-109.

Heaton, J.B. (1988). Writing English language testing handbook. New York, NY: Longman.

Kim, M. (2012). Genre based approach to teaching writing. Asian ESP Journal, 8 (3), 33-39.

Kim, Y. \& Kim, J. (2005). Teaching Korean University writing: balancing process \& genre approach. Asian EFL Journal Quarterly, 7(2), 69-90.

Kongpetch, S. (2006). Using a genre based approach to teach writing to Thai students: a case study. Asian ESP Journal, 5 (2), 21-33.

Richards, J.C. (2006). Communicative language teaching today. Singapore: Seameo Regional Language Centre.

Seniati, L., Aries,Y.,\& Bernadette, N.S. (2011). Psikologi eksperimen. Jakarta, Indonesia: Indeks.

Trong, T.L.U.U. (2011). Teaching writing through genre based approach. BELT Journal Porto Allegra, 2(1), 121-136.

Wang, C. (2013). A study of genre approach in EFL writing. Theory and Practice in Language Studies, 3(11), 2128-2135.

Yang, W.H. (2012). A study of students' perceptions and attitudes towards genre based ESP writing instruction. Asian ESP Journal, 8(3), 89-95 